\title{
القول بين التحديث والحداثة والمعاصرة
}

\author{
د / الا عزمي الشربيني الطرسلى ماضيى \\ الأستاذ المساعد بجامعة الإمام عبد الرحمن بن فيصل

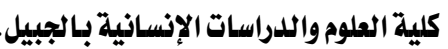

\section{الملخص:}

هدفت الدراسة إلى تأصيل لدعنى الحداثة والتحديث والمعاصرة في معانيها اللغوية و الاصطلاحية

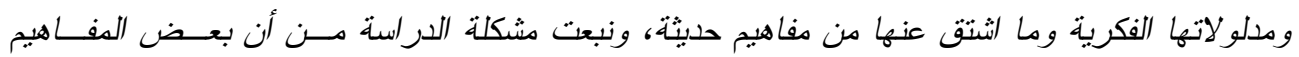

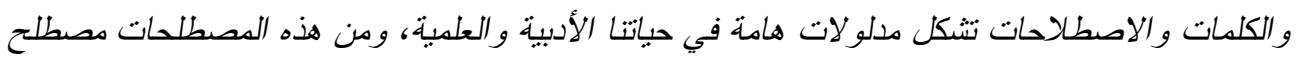

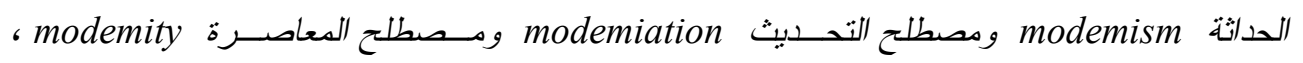

مصطلحات هامة ترجمت إلى اللغة العربية، واستخدت بدعنى واحد فقط، و بشكل عام بدعنى الحداثــة،

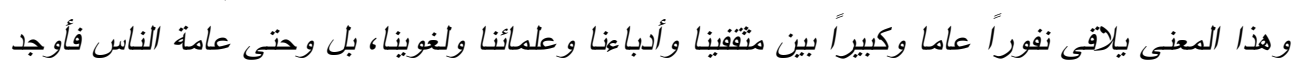

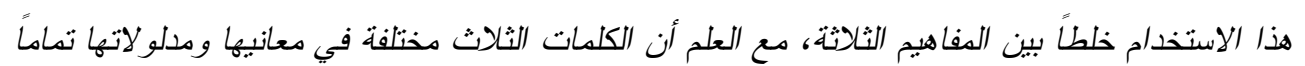

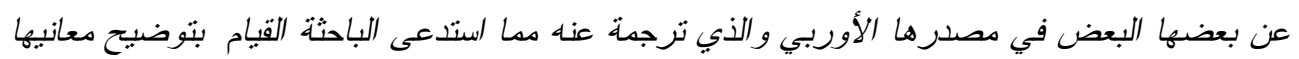

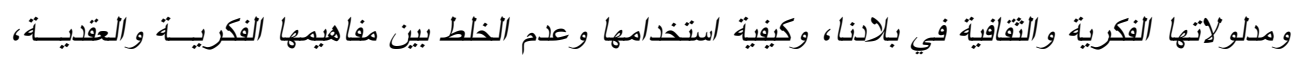

وأوصت الباحثة بأهمبة استخدام مصطلح التحديث و المعاصرة و الحد من استخدام مصطلح الحداثة.

الكلمات المفتاحية: التحديث - المعاصرة - الحداثة - رأي - العلماء - اللغة العربية

\section{Abstract}

The study aimed to consolidate the meaning of modernity, modernity and contemporaryity in its linguistic and idiomatic meanings and its intellectual connotations and modern concepts derived from it, and the problem of the study stemmed from that Some concepts, words and terminology constitute important meanings in our literary and scientific aspects : modernization, contemporary and modernity; important terms that have been translated into Arabic and have been used in only one sense. The term " modernity" in general faces aversion among our intellectuals, writers, scholars and linguists which in turn led to confusion among the three concepts. Such a confusion in using the three concepts necessitated the researcher to clarify their intellectual and cultural meanings, implications and connotations in our country. The researcher also recommended the necessity of using the concepts of modernization and contemporary and eliminating the use of modernity. 
تعرف الحداثة كبديل لغوي و اصطلاحي يلقى

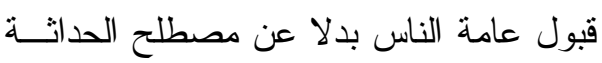
الذي يلاقي النفور العام و الكر اهية كثير ا في

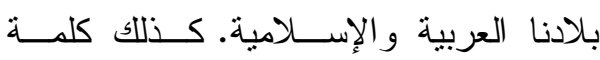
التحديث ظهرت لها مشتقات تقسر ها وتعبــر

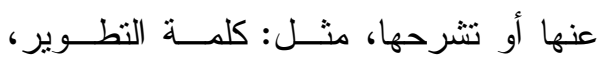

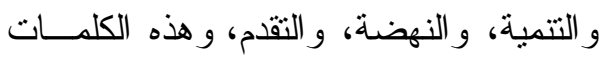

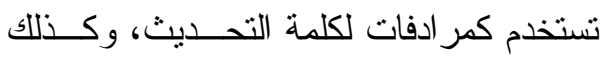

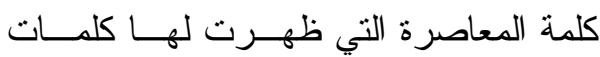
ومعاني تشرحها وتفسرها، منل: مــصطلح

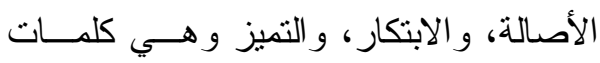

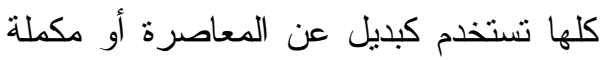
لها، و هذا أوجد خلطا بين كثير ا من الكتــاب

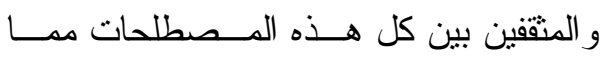

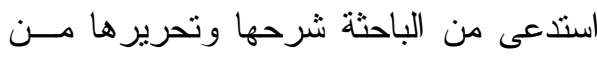

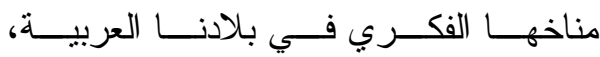
ومعرفة معانيها في بلاد الغرب في محاولـــة

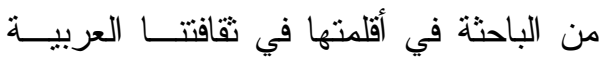

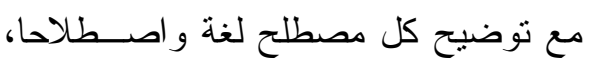

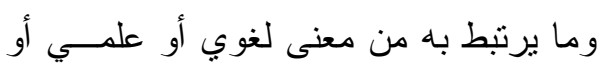
خر افي أو تاريخي، أو أسطوري أو ديني أو لوني

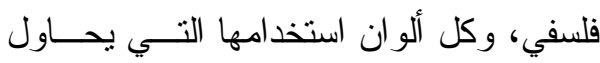

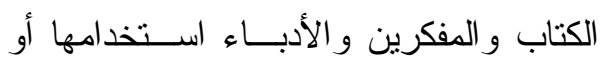
التعبير عن معاني وأفكار محــددة يحــاول

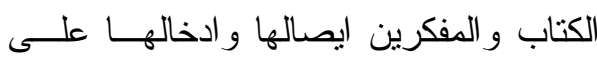
قر اهه أو جمهوره أو مــن يخــاطبهم بهـــنه
اختلطت مفاهيم ثثلاث كلمات أوربيـــة

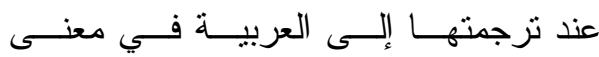

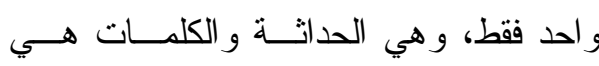

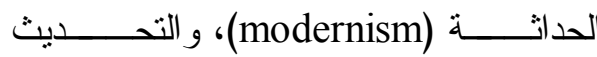

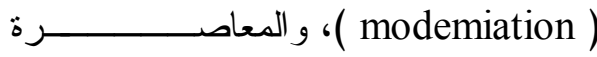
( modernity)

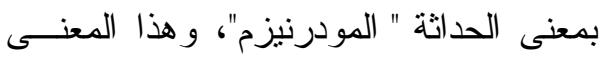
يلاقي نفوراً عاما وكبير ا بين منققينا و أدباءنا

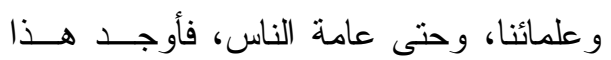
الاستخدام خلطا بين المفاهيم الثلاثة رغم أن الكلمات الثناث مختلفة في معانيها ومدلو لاتها تماما عن بعضها البعض، بل اثتّق من كـلـل كلمة كلمات واصطلاحات كثيرة، فأوجد هذا لهان في كثير ا منا نحن العرب خلطا في المفـــاهيم

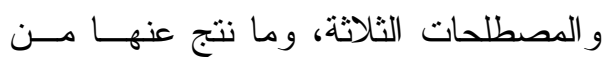
مفاهيم، فاستذعى ذلك من بعـض البــاحثنين و المثقفين توضيح معاني هذه الكلمات الثناث

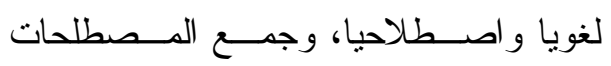

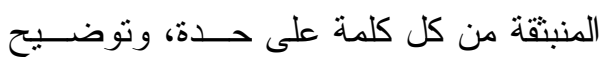

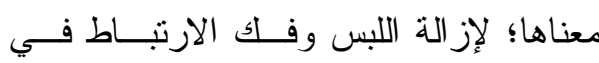

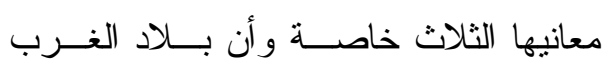
الأوربي تستخدمها بمعاني متعددة لأنها منشأ

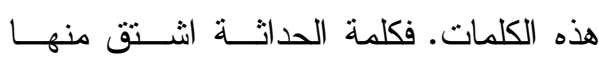

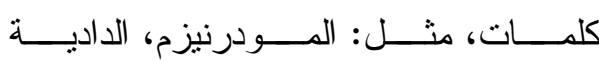
الميتافيزيقية، اللائكية العلمانية، و المستقبلية، و السريالية، و الانطباعية وكل هذه الكلمــات 
مصطلح الحداثية و الحداثية خلفيتـــه اللغويـــة

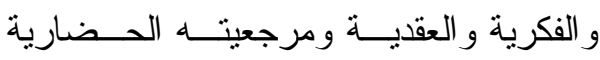

و الفلسفية. التعريف الأوربي

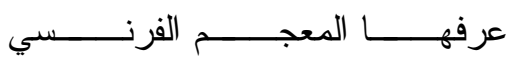

peritvobert

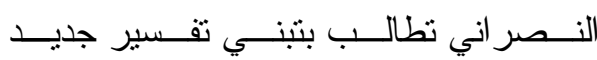
للمعتقدات والأصول اللاهوتية التقليدية وفق لنق

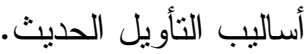

كما عرفها الأوربيون بأنهـا: ثـورة

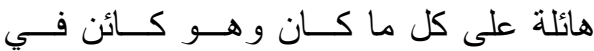

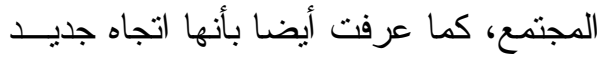
في المجتمع تتبنى العلم و التكنولوجيا و العقــل كآليات وحيدة للتعامل مع الو اقع. وعرفت أيضا بأنها: صـــورة نـسق تجسد نمط اجتماعي متكامل، وملامح نـسق صناعي منظم ومتكامل يقوم على العقلانيــة في مختلف المستويات و الاتجاهات. وعرَّفها كل من مــاركس ودوركــايم وغير هم بأنهــا: نـستق مــن الانقطاعــات التاريخية عن المر احل الثابتة، حيث تهـيمن بـن التقاليد و العقائد ذات الطابع الشمولي(؟). وعرَّها الفيالـسوف الألمــاني كـانط

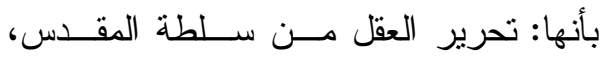

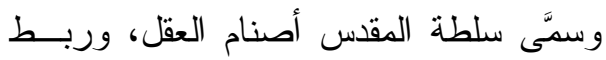
بين الحداثة و الحرية الكاملة.
المصطلحات مع توضيح الأخذ بالمــصطلح، و الذي يناسب الحال و المقام عند اســتخدامه؛ وذللك حفاظا على فن الكتابة الأدبية و العلمية في لغتتا العربية، وعدم ادخال مـصطلحات و إحلالها محل بعضها مما أوجد نوع من قلة

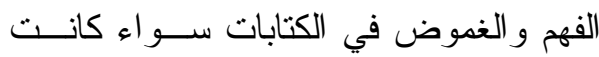

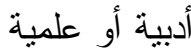

وعليه فيجب توضيحها لتناسب ثقافتتا

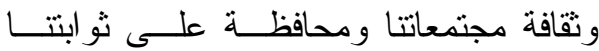
الفكرية و الأدبية و هذه مشكلة البحث. أولا): تعريف الحداثة و الحداثية المودرنيزم modernism

لغة: ظهر مصطلح الحداثة -الحداثية

- المودرنيزم، مترجم من الإنجليزيـــة إلــى العربية، وهي لغة مشتقة من فعـل حسدث يحدث حدوثا وحداثة، و الحديث نقيض القديم، فهو محدث وحديث (modernism)، يقابلها في اللغة العربية بناء ما يسسمى فـي علــم الصرف بالمصدر الصناعي، ويتم زيادة باء مشددة بعدها هاء في آخر الاسم، كالوطنيــة

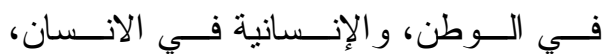
و الصناعية في الصناعة ومعناهـــا اللغــوي والإسي يعني الابتداء وأول الأمر (1). أما دلالتهـ ولهـ

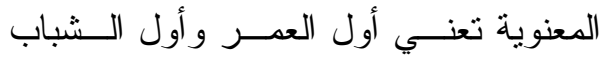

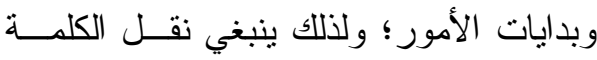

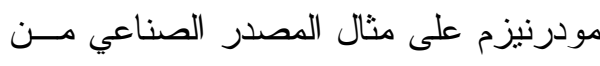
اسم الحداثة وهو الحداثية، بحيث نفهم مـنـ هـن 
أوروبا، منل: ( هوبز، وبيكون، ديكـارت،

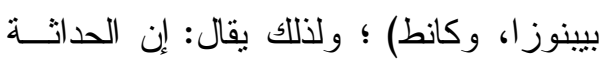

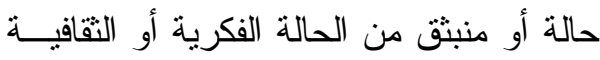
التي تسبق الحالة التالية، و هي لا تخص زمنا

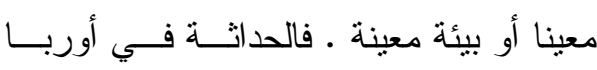
تعددت وتطـــورت مـــع تطـــور الحــــارة الأوربية؛ ولذلك تعرف الحداثة

بأنها نظريات و أفكــار جديــدة فــي المجتمع، تعمل على زو ال البنيــة التقليديــة

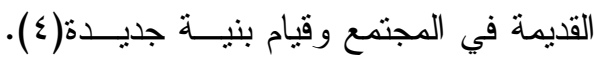
وتعني بذلك التجاوز ورفض النقاليد وكل ما

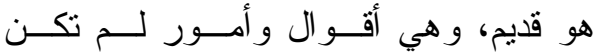
معروفة من قبل، بمعنــى أن لكـل عـصـر حداثثه، وهي بذلك حركة تصويب وتغييـر

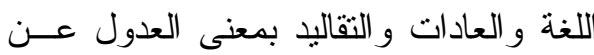

النمط السائد(0).

ومما سبق يتبلور مــصطلح الحداثــة

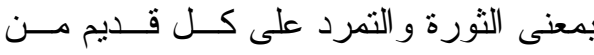
موروث ثقافي وحضاري وديني، وعـادات

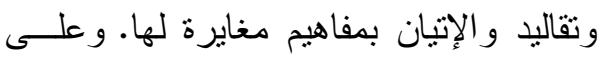
ذللك يمكن تحديد الأصول الثلاثــة للحداثــة المودرنيزم بالآتي:

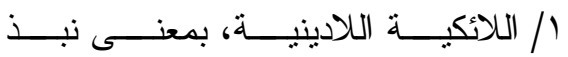

المرجعيات المطلقة و الأحكام الغيبيـــة الإيمانية وما إلى ذللك ممـــا بـسمونه

متعاليات ميتافيزيقية.
و عرَّفها "جوس أورتيكا" بأنها: هـــدم

قدمي لكل القيم الإنسانية التي كانت سائدة في الأدب و الحياة الاجتماعية.

وعرَّفها "نـــورين" بأنهـــا: اســتنبدلت الحداثة فكرة الله بفكرة العلم بحيث تقتــصر بـت

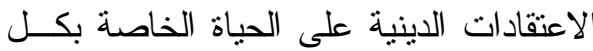
فرد. و هذه التفسيرات عند علماء وفلاسـفة الغرب نشأت في ظل سلطة رجــال الــدين و الكنيسة و الإقطاع في

أوروبا؛ لذلك يؤرخ المؤرخون بدايـــة

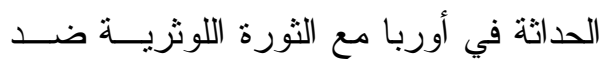

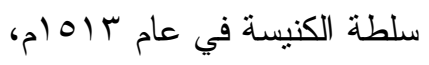
و البعض يقول: إن نشأة الحداثة مـــع

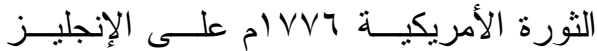
وتحرير أمريكا من كل سلطة أو مع بدايــة الأنسية

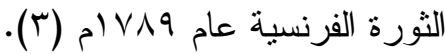
و على ذلك اعتبر زمن الثورات فـي

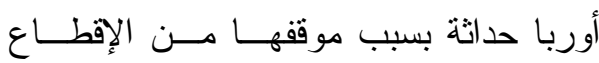
ورجال الكنيسة، وكذللك في عصر التتــوير

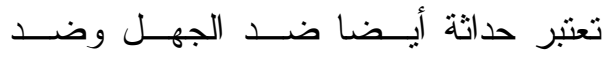

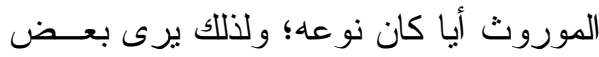

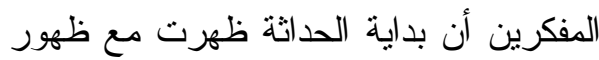

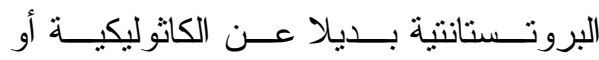

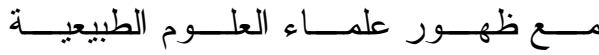

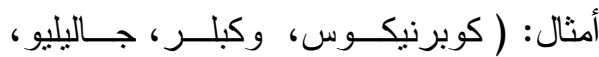

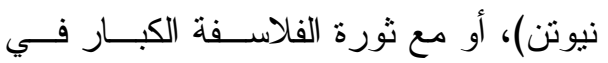




$$
\begin{aligned}
& \text { / / الإنسان بما هو المركز وقطب المدار، وظهرت في وسط أوربا باسم التكنولوجيــا، }
\end{aligned}
$$

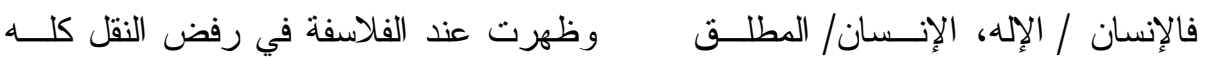

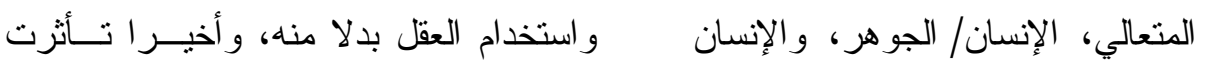

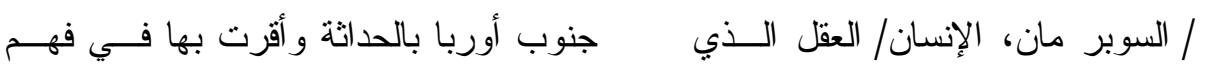

$$
\begin{aligned}
& \text { يصنع حياته، ويطــور نــــ عيـشه وتغيير النص المقد. } \\
& \text { وخلال القرون الثناثة الأخيرة تبلـــور } \\
& \text { مفهوم الحداثة في أوربا وظهرت انعكاســاته }
\end{aligned}
$$

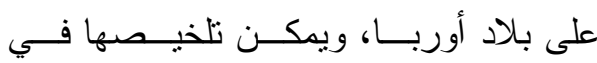

$$
\begin{aligned}
& \text { r/ الرؤية الطليعية التجريبية الديكارتيــة، الآتي: } \\
& \text { / الزحف الكبيــر للثقافــة الاســتهلاكية } \\
& \text { و المادية، ومنطــق الــربح الــسريع } \\
& \text { وتصـاعد النزعة الفردية في المقابــل؛ }
\end{aligned}
$$

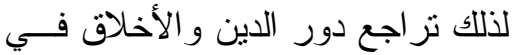

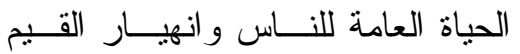

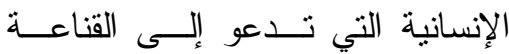

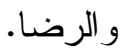

$$
\begin{aligned}
& \text { / / زيادة الإحساس بغربة الذات الفرديــة، } \\
& \text { وتمزقها بسبب التحولات الكبيرة التي } \\
& \text { شهدتها المدنية الغربية بعـــ ظهـور }
\end{aligned}
$$

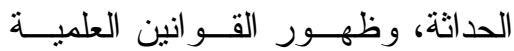

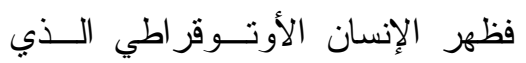

$$
\begin{aligned}
& \text { يملك السيطرة بالعلوم الحديثــة، ثـم }
\end{aligned}
$$

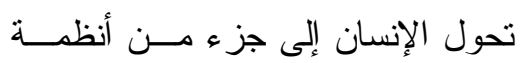

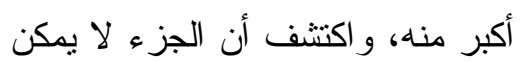

$$
\begin{aligned}
& \text { أن يتحول إلى الكل. }
\end{aligned}
$$

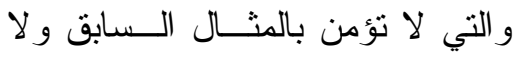

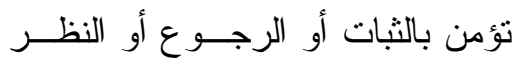

$$
\begin{aligned}
& \text { إلى أصل أو نموذج، أو مبدأ أو اعتقاد }
\end{aligned}
$$

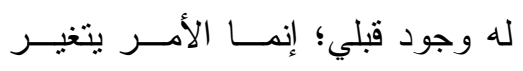

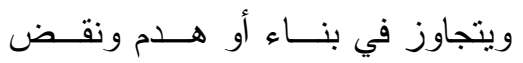

$$
\begin{aligned}
& \text { مستمر (7). } \\
& \text { وقــــــــــرت الحداثـــة بمــصطلح } \\
& \text { modernism }
\end{aligned}
$$

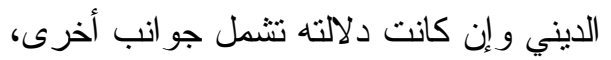

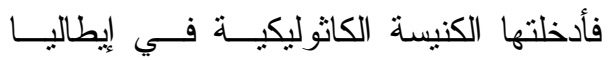

$$
\begin{aligned}
& \text { كمحاولة لتطوير كل العمليات التجديدية التي } \\
& \text { شهدها الفكر المسيحي الكانوليكي مستقيدا من }
\end{aligned}
$$

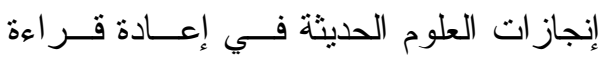

$$
\begin{aligned}
& \text { النص الديني في الكتاب المقدس مــن بدايـــة إدة }
\end{aligned}
$$

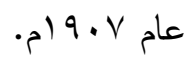

$$
\begin{aligned}
& \text { ولهذا نجد أن الحداثة شـملت شــمال }
\end{aligned}
$$

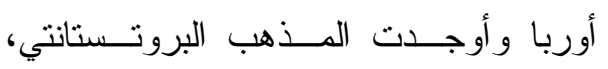


قامت على أساس الغلو بالــشعور الفــردي ومهاجمة المعتقدات و المؤسسات التقليديـــة؛

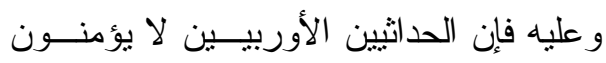

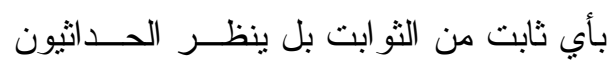

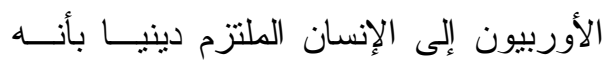

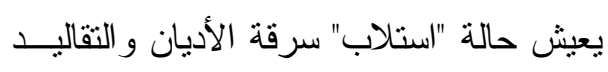
الثخصية، و لا سبيل إلى فلك طوق الاستلاب

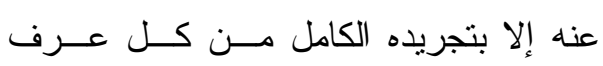
و إعلاء قيمة الفرد ومنحه حرية مطلقة يصبح

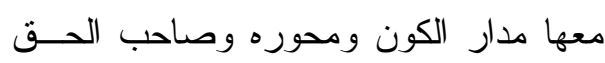

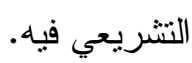

ومن الواضح أن الحداثة الغربيــة لا لانهان

تؤمن بأي ثابت من الثوابت، فهي نيار يعادي الوافي لان

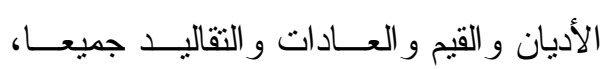

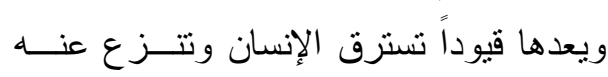

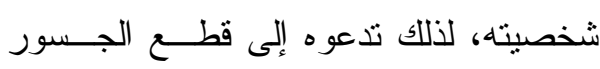
معها.

يقول الفيلسوف "لامونت" موجزاً مـــا يسميه النزعة الإنسانية للحداثة أن الإنسان لا لانول

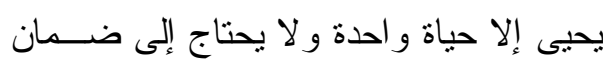

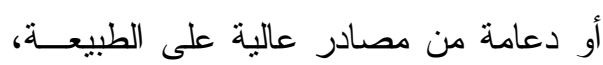

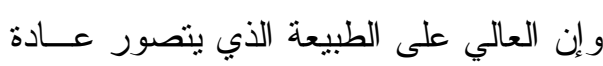
على شكل آلهة سماوية ليس موجودا على أية لئل

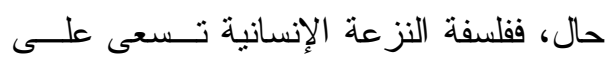

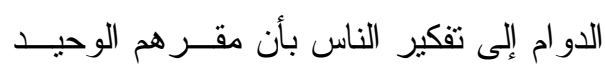

هذه الحياة الدنيا (9). r/ تز ايد مذاهب الثكك في كل شيء بعـــ نزاجع دور الإنسان وتز ايد الاعتقــاد بمذهب النسبية في كل شيء.

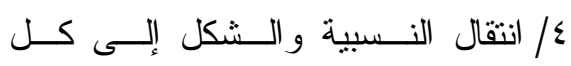
المجالات، مثل: قر اعة النص الــديني، ولنه

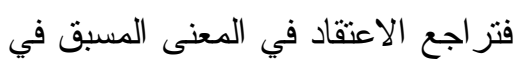

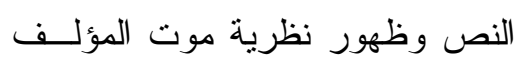
و انتهاء سلطته. / / تر اجع دور الدين في المجتمع، فتقـــوم البيولوجيا وما حملته من اهتمام بجسم

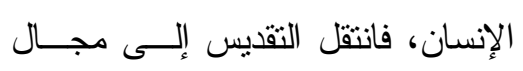

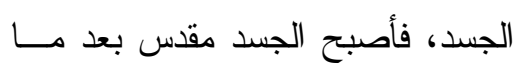

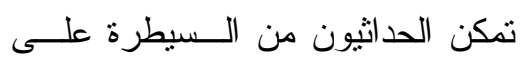
غيبيات الكنيسة. ا/ / تمجيد العقلانيـــة و التقكيــر العقلانـــي

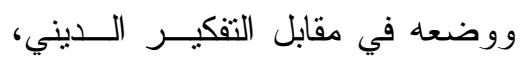
و اعتبار هذا الأخيــر أمسام الحداثــة فئة

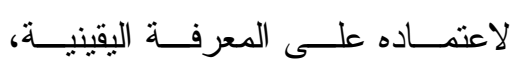

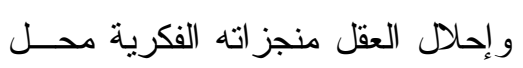
الله في مركزية المجتمع (V).

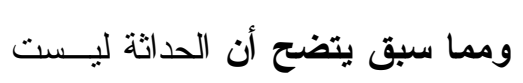

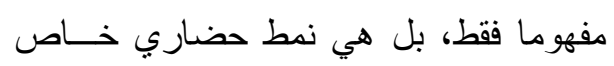

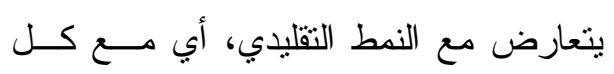
الثقافات و على النقاليد السابقة عليه.

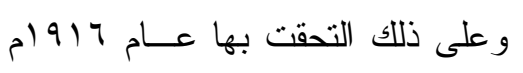
الدادية، وهي حركة وموجة حداثية جديــدة 
وكذلك يتبنى معظم الحداثيين العسرب

موقعهم من الدين، كما تنبت الحداثة الغربية

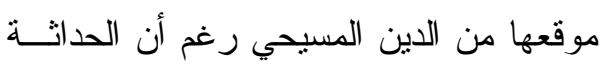
ظهرت الحداثة العربية فـي مطلـع

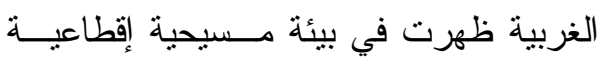
القرن العشرين كمصطلح مثرجم من اللغات الأوربية إلى اللغة العربية على يد كثثراً من من من مخالفة لبيئتنا الإسلامية الذي يدعو فيها الدين لين

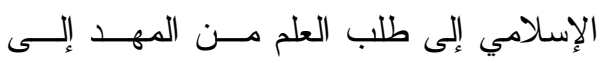
اللحد، ويدعو إلى التكافل والرحمة و الصدقة و الذكاة على الفقر اء، بل جعلها ركــن مــن

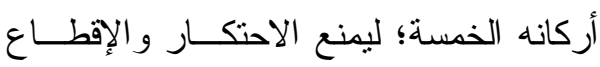
وغير ها من صنوف التـسلط الطبقـي فــي التهـي المجتمع(1 (1). المرجع السابق نفسه

وقد ظهرت الحداثة العربية بتعريفات

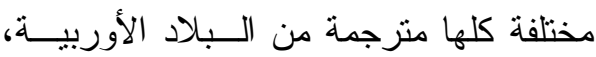
وكلها تحمل معنى واحد تقريبا، وهو الثورة على الموروث و المعتقد السائد و النمطي بــلـ وهـل

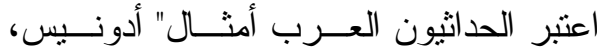
غالي شكري" وغير هم من الحداثيين العـرب أن ثورة الخو ارج و الزنج و القر امطة حادثــة عربية. وأخذ الحداثيون العرب ينبشون فـي كتب التزاث لاستخر اج كل شاذ ومنحــرف

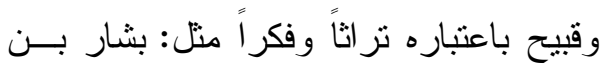
برد، وأبو نو اس رغم أن في شعر هم مروق

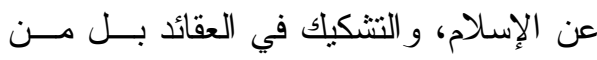
تحدث منهم في الإسلام وضع معه مصطلح

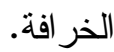
العلماء و المفكرين و الأدباء و علماء اللغة، وقد التد

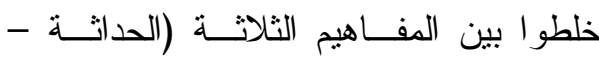

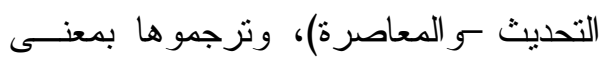
واحد، وهو معنى الحداثة في محاولة مـنـهم وترهم

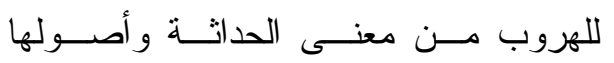

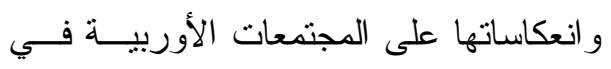
محاولة منهم ليتقبلها الإنسان العربي وإلباسها لأنهات

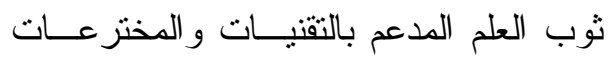
الحديثة خاصة بعد تلقيهم ترجمات الحداثــة

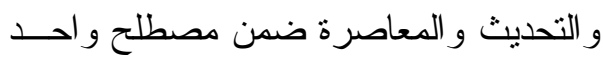
هو الحداثة.

وقد بدأ الحداثيون العرب باللغة علـى أساس أنها ترتبط بينها وبين الفكر، فــدعوا إلى إعادة بناء بنية التعبير في اللغة العربيــة

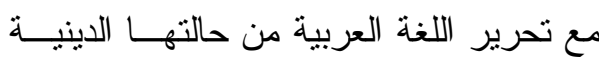

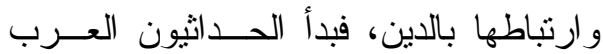

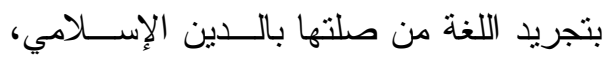

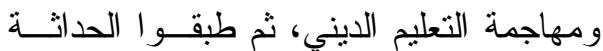

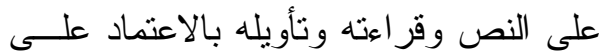

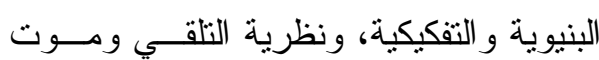

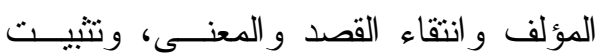

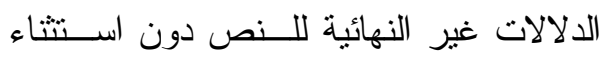
النصوص الدينية من ذلك (• (). 
الو اقعية وهي الارتقاء بــــا فــوق الطبيعــة

وفوق الموروث للتعبير عن الواقع المرئــي لأدي

حسب تلاك التصور ات.

و السريالية المستقبلة، كــذلك ظهــر

مذهب الانطباعية، وهو تفسير الواقع المعاش

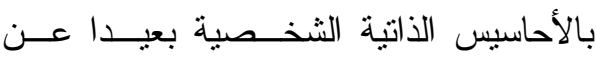

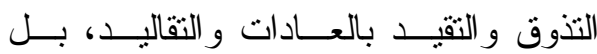

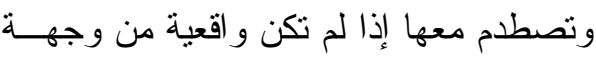

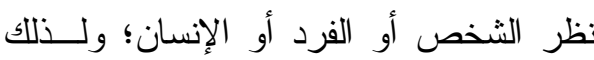

يطلق عليهم التأثيربين أحيانا (r ()).

كما ظهر مصطلح من مـصطلحات

الحداثة، منل: التمايز وهو لتوصيف التحديث وتعني حداثة الظو اهر وتقيم العمل وذللك عن طريق حركة التقنية و التكنولوجيا و إدخالهــا

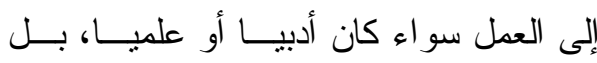
وظهرت أفكار كثثرة عن الحداثة في شـــل

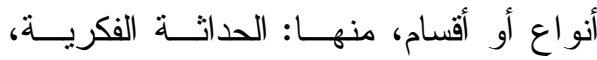

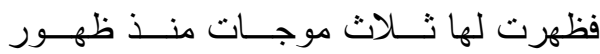
مصطلح الحداثة وهي: الموجات الزراعيــة

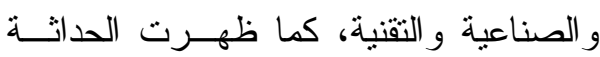
الاقتصادية، وهي تشمل التحول الاقتــصادي

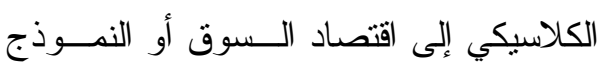

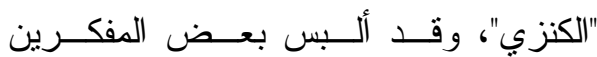

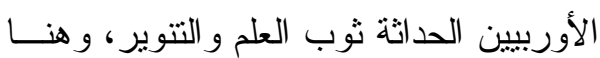

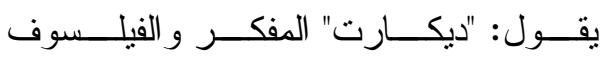
الفرنسي:" إن الحداثة تضع العقل الإنـسـاني في وضع طبيعي للوصول إلى معرفة حقيقية
و على ذللك عرفها بعض المفكـرين

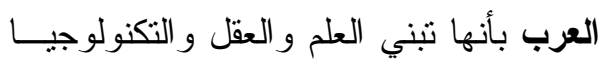

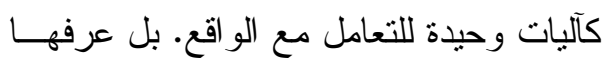

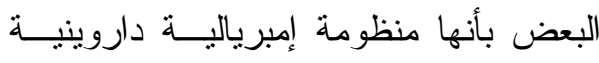
تحكمها العقلانية المادية في منظومة الإنسان

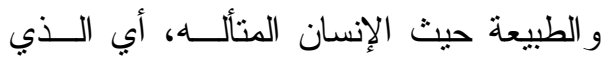
يجعل نفسه مركزاً للكون، ويجعل أوربا هي الإنسان

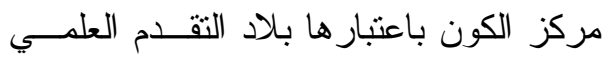
و التقني(r (I).)

هذه المعاني للحداثة ظهرت في مناخ يغـــاير المجتمعــات العربيـــة و الإســـلامية

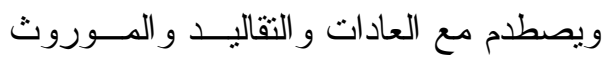
الديني في عالمنا الإسلامي ومنطقتنا العربية، كما يصطدم مفهوم الحداثــة مــع العــادات و التقاليد المجتمعية، ومن ثم حسـاول دعاتــهـ

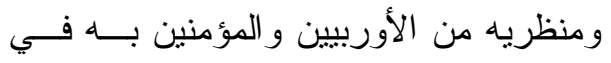

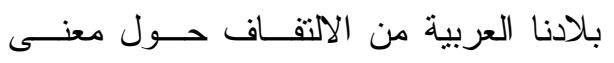
الحداثة بإخر اج مذاهب وتعاريف جديدة حتى

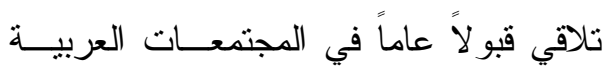
و الإسلامية، ومن هذه المذاهب المنبنقة عـنـ لـن الحداثة ظهر مصطلح المستقبلية وهي النظرة إلى المستقبل و الجديد منه وترك الماضــي،

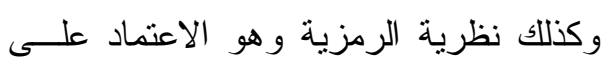

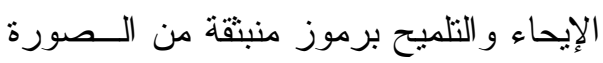

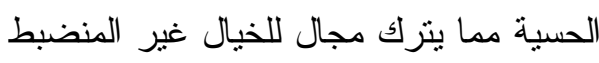
بالعقل و الثرع أو الدين، وكذلك المذهب أو

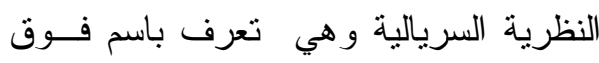


فكرنا وتز اثثا و عقيــدتتا وقيمنـــا الإســلامية

$$
\text { و العربية. }
$$

ويجب استبدال هــذه المـصطلحات

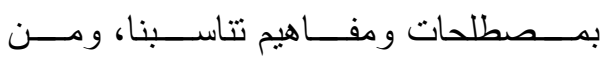

مصطلحات الحداثـة: التمـايز والمــستقبلية

و السريالية" فوق الو اقعية"، و الانطباعيــة، أو

حتى مصطلح العلمانية يعرض كبديل مناسب

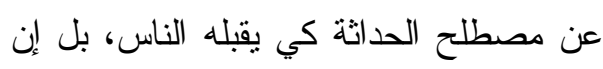

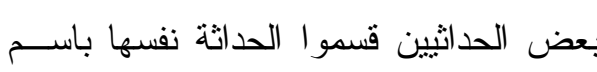

الحداثة اللاتينية بعد صدور قانون اللائكية "

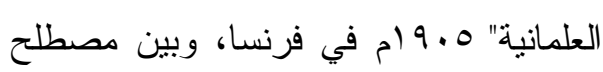
الحداثة الانجلو سكسونية، والتي نشأت فـي في

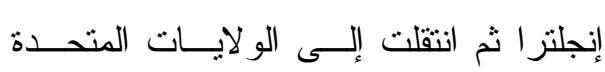
الأمريكية، و التي استخدم ثلاثـــة: العلماتيـــة

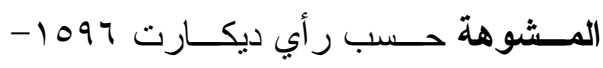
. 10 (م، وهي الثك الممنهج في كل شـيء

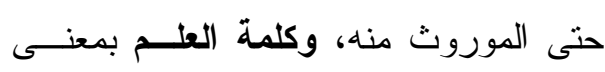

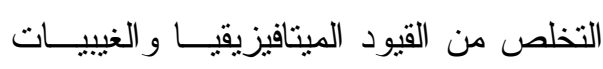
جميعها، و الأخذ بالمنهج العلمي الذي لا يقر لانين إلا بما تثبته التجارب.

وربط بعض المثقفين العرب بالتحديد

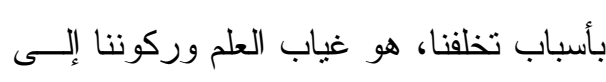
الغيبيات مع العلم أن الإسلام لم يكن موصداب

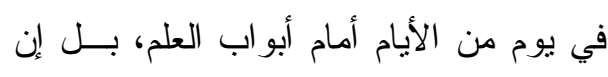

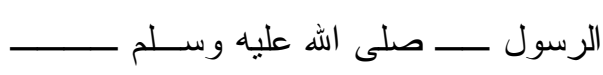
قال: " من سلك طريقا يلتمس فيه علما، سهل
نو افق اليقين الفعلي، فعنده العقل هو المرجع

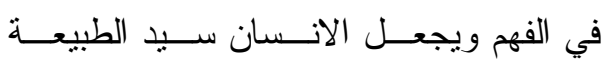

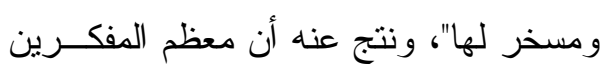

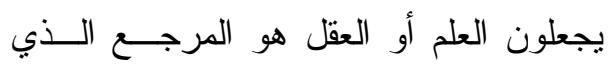
يعتمدون عليه دون الرجوع إلــى العـادات لئل

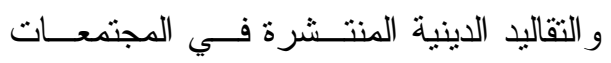
الإسلامية و العربية، ومن هنا جاء الاصطدام

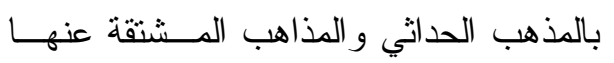
ورفضها من قطاع عريض مــن المجتمــع الإسلامي و العربي مما يستدعي من استخدام

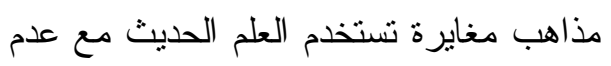
إهمال القديم و التزاث من عاداته وتقاليده التي لئني

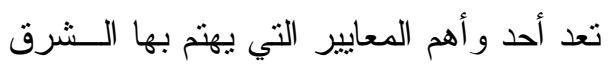
الإسلامي و العربي.

\section{مما سبق ومن خلال تلك المصطلحات}

المفسرة لمصطلح العداثة، أنـــه مــصطلح

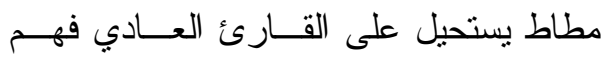

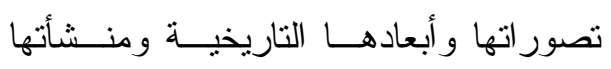

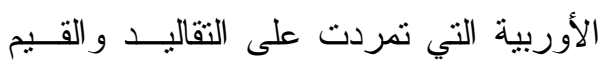
و الموروث، فلا يمكن أن نأخذ بالحداثــة أو الورئ

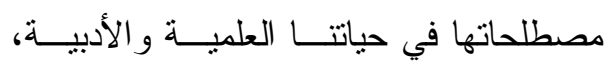
ويجب الحرص في استخدامها فهـي ليسـت فئ

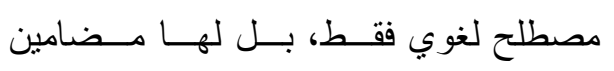

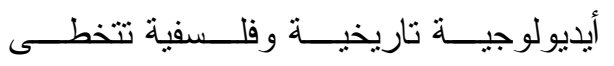
المضمون اللغوي العادي، وكذلك المضامين

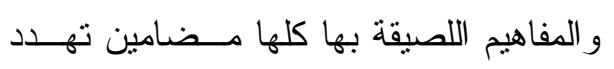


تعمله"، وتقول العرب " لا حدث بالنعمة"، أي

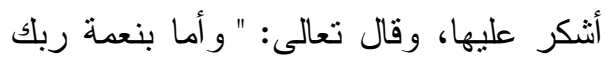
فحدث".

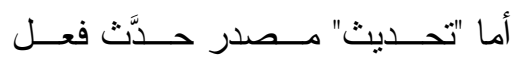

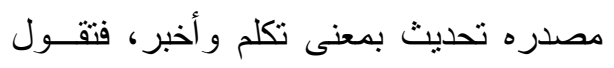

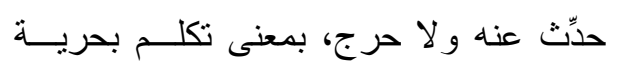

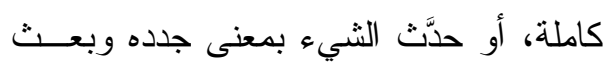
فيه الحداثة و التطوير (ع ( ).

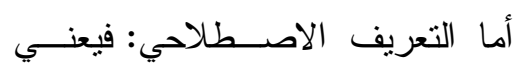

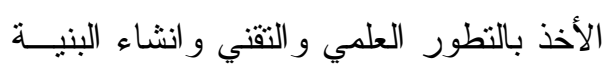
التحتية للمجتمع في كل مجالات الحياة سواء

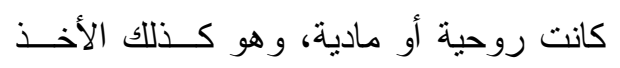

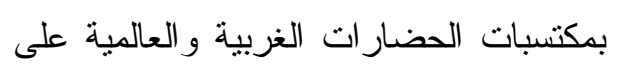
السواء مع وجود سياسة و اضحة للمجتمــع

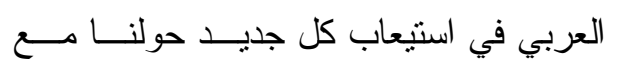
الأقدم و اقتحام كل المـستويات الحــــارية المجاورة و الأخذ منهــــا بالاقتبــاس و النقــلـل و التقليد وفق ما يتتاسب ويتماثشى مع عاداتتا

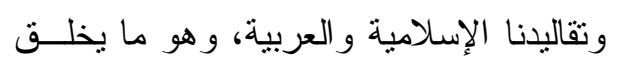

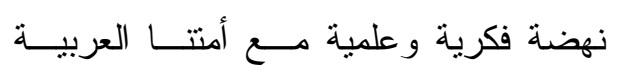

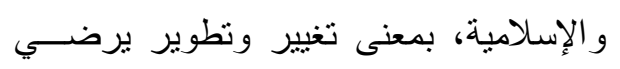

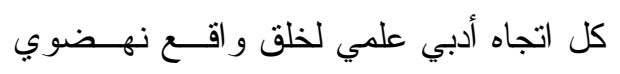
تحديثي تطويري قوي.

وبذلك يعتبر التحديث أحسـد أســباب التقدم، فهو وسيلة للتتمية الأدبية و الاقتصادية

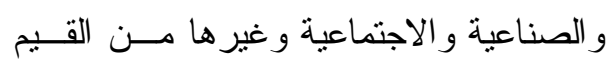
المعروفة اليوم بالنهضة و التتمية.
الله له به طريقا إلى الجنــة"، بــشرط عــدم مخالفة الضو ابط الثر عية. النقطة الثالثة التي نادي بها العلمانيون الحداثيون هي: الحرية الفرديـــة/ الليبر اليـــة،

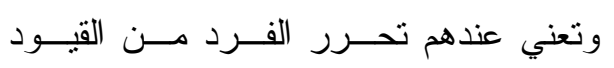
و الأغلال ، وتجعل المرجعية فـــي الأحكــام الدينية و الدنيوية إلى الثعب مما جعل الحرية ولجية الفردية هي الغاية الأولى والرئيـسية التـي ولئي

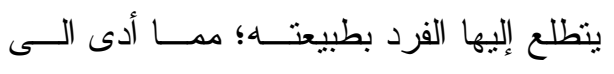
ظهور بعض الأمر اض الاجتماعية الخطيرة

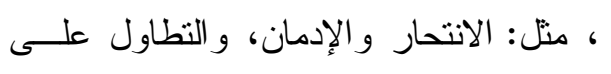

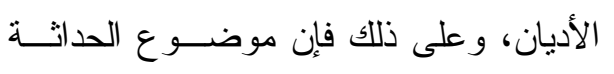

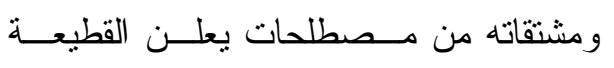

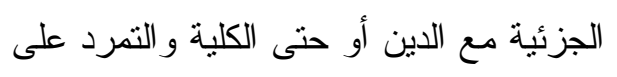

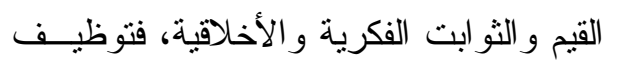
مصطلح الحداثة بتطلب الحذر . ثانيا): مصطلح التحديث :(modernization)

مصطلح مترجم من الإنجليزية إلـى

العربية بمعنى التحديث، ومعنــاه اللغــوي:

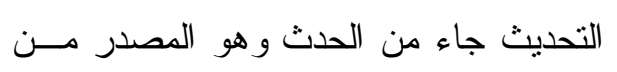

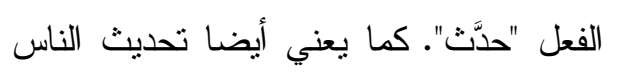

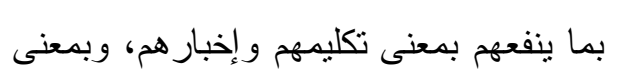

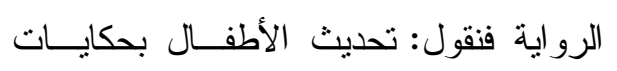
عجيبة أو تحديث النفس أخطار ها و إثتعار ها،

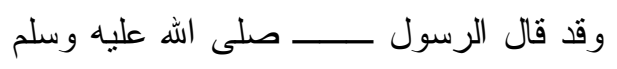

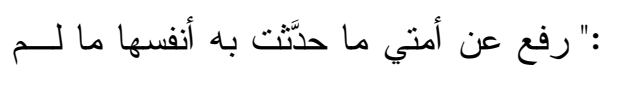


تطوير وتنكيف بشكل مستمر مـــع منطلبــات

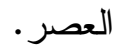

و عليه فالتتمية تـسبق التحــديث؛ لأن

التتمية تعتمد على خليط من النظريات حول كيفية تحقيق تغير مرغوب فيه في المجتمــع بأفضل السبل، و التي تعتمد على مجموعـات من التخصصات و المناهج الاجتماعية التـي ليكي تعمل في عــدة مجــالات منهــا: الــسكان، و الصحة العامة، وعلــم البيئــة، و الهندســـة و العمارة، وكذلك الفنون الأدبيــة المحليــة، ونقل الفنون الأدبية من اللغات الحبـــة بـــــا يناسب احتياجاتتا، ويتتاســب مــع طبيعـة المجتمع و عاداته وتقاليده. وكـــللك الناحيــة الاقتصـادية و التعليم، وكذلك دمــج الأفكـار بمعنى امتلاك المجتمع المهارة و المعرفة التي تتاسبه، و هي ما تعرف باسم عملية التحديث.

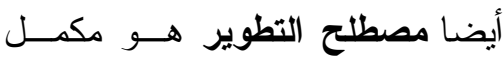

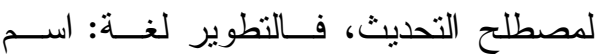
مصدر طوَّر، فتطـــور الـصناعة بمعنـى تحسينها إلى ما هو أفضل، و المعقول منه هو

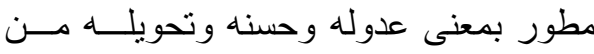

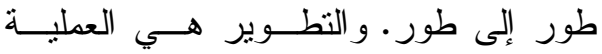
المسؤولة عن تجويد الخدمة، بمعنى التتظـــيم و التحسين و التعديل للأفضل (1 ( ). أما التطوير اصطلاحا: فيعني التغيير أو التحويل التدريجي الذي بحدث فــي بنيـــة

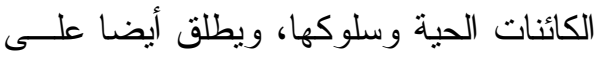

ولهذا اشتقت من التحديث مصطلحات

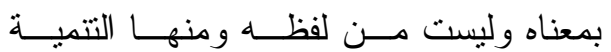

$$
\text { و النظوير و النهضة (10). }
$$

فالتنمية: لغة اسم مصدر من الفعـل

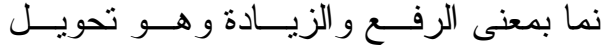
المو ارد و الرفع و الزيادة، و هـــي الاســتمر ار

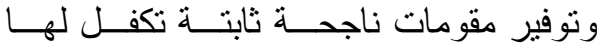
الاستمر ار ، وكذلك تتميــة الـسـوق وتتميــة المبيعات تحويل المــوارد الطبيعيــة غيــر المستثرة إلى مو ارد مستثمرة (7 (1). التتمية اصطلاحا: أداة نستطيع الدول

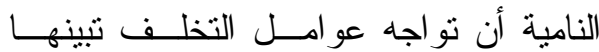
خصائص المجتمعات المتقدمة، وهي كــللك تطوير وتحويل العلاقات الإنسانية والمقومات

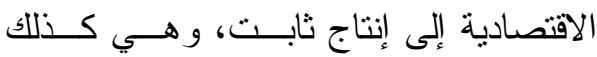
التكيف المستمر بخطو ات ثابتة. نلاحظ اتفاق التتميــة مـــع التحــديث خاصة وأن التحديث يؤدي إلى تضييق هـــوة

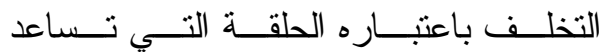

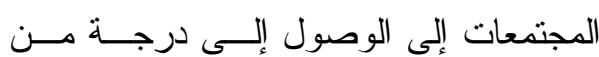

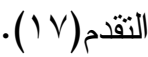

وعلــى ذلـــك يجــب الفـصل بــين

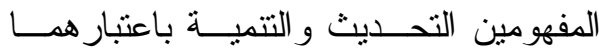

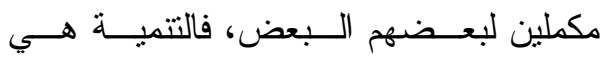
الاستقلال الرشــيد للمـــوارد و التكنولوجيــا، وتظوير النظم و التحضر و التعليم، فالتتميــة 
ولذلك بسمى بداية العصر الحــديث

عصر النهضة، وهي الفترة الانتقاليــة مــن

العصور الوسطى إلى العــصور الحديثــة.

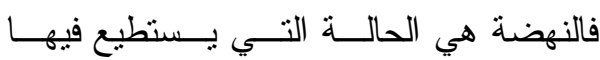

المجنمع التخلص من المعوقات و القيود التي

تعيقه من الانطلاق، فالنهضنة هبة مجتمعيــة

تسعى إلى إكساب الحضارة القومية قـدرتها

على إنتاج المعارف و المهار ات في تعامـلـل

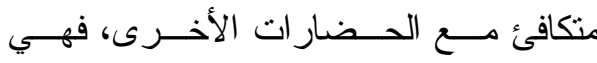

المحصلة النهائية لعملية التغيير و النهــوض الته

$$
\text { و التحديث (r) ( }
$$

ومن هنا جاء ارنباط مصطلح النهضة

بمصطلح التحديث، فالنهضة بداية التحديث،

وظهور النهضة هي المحصلة للتحديث في أي مجتمع، ولذلك سمي القرن التاسع عـشر عصر النهضة العربية.

modernity ثالثا): مصطلح (لمعاصرة مصطلح يترجم بمعنى الحداثة ولكــن معناه مخنلف تماما عـن معنـــى الحداثــة، ولمعرفة ذللك نقف على معنـــاه فــي اللغــــة معنـ

$$
\text { و الاصطلاح. }
$$

المعاصرة لغة: اسم مصدر ه عاصــر

يعاصر معاصرة، بمعنى عـــاش معـــه فــي

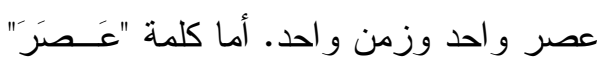
فعل فهو عصر بعصر ، ويعصر عصراً فهو عاصر و المفعول معصور، فعصر المؤسسة
التغير التدريجي الذي يحدث فــي نزكيــب المجنمع أو العلاقات و النظم و القيم، ويعنـي لئي تحسين أداء عمل الأفراد ومنحهم الفرصــة للنمو و التطوير و التحديث وضمان التعاقــب العمالي و الإداري، و على ذلك ارتبط مفهـوم

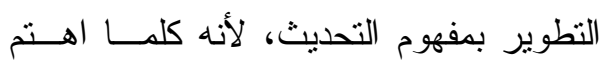
بعملية تحديث وتطوير للمقومـــات الأدبيــة و العلمية و الموارد البشرية، فهي بذلك أحــــ معاني التحديث مع المعنى السابق وهو معنى التتمية (19).

و هذه المعاني لها أهمية في التطوير و التعبير عن تحضر المجتمع وتطوير ذاتــهـ والأخذ من المخترعات الحديثة بما يناســب أوضاع مجتمعنا، ومن هنا جـــاءت أهميــة مصطلح التحديث وكيف أنه يختلــ عـن مصطلح الحداثة.

أما مصطلح النهضة لغة: تعني الطاقة و القوة، وهي الوثبة في سبيل التقدم، فكثيـر النهضة كثير الحركة وفعلها ثلاتي من نهض ينهض فهو ناهض، تقول نهض إلى أبيـــه أو لأبيه أي تحرك مسر عا (·r). أما مصطلح النهــضة الاصــطلاحي فيعنى به: حركة إحياء التزاث القديم و إدخاله في مجالات الحياة الحديثة مع تطويره بمـــا يتتاسب مع الفنون و الآداب، و العلوم وطرق التعبير و الدر اسات الحديثة مع المحافظة على أسسنا الفكرية و الدينية و الاجتماعية. 
و المقصود بها فـــ اللغــة: الــرأي

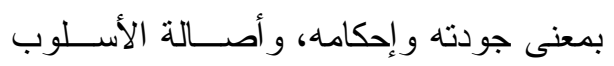

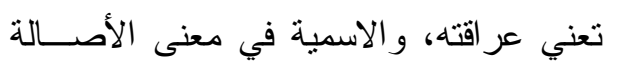

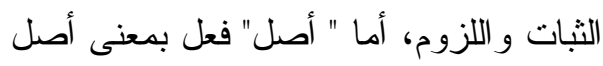

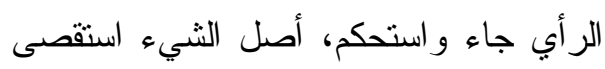
بحثه حتى عرف أصله، وتثول طبق الأصل

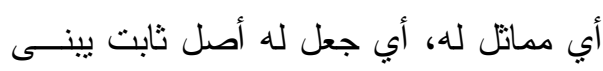
عليه(乏) ب).

أما اصطلاحا: فتعني الابتكار و التميز

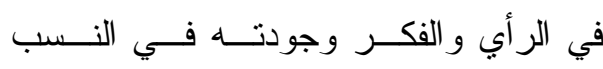

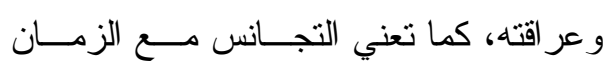

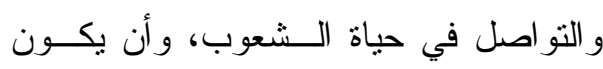
حاضرنا مبني على تفكير معمق لاســتخدام تطبيقات جديدة لم يسبق لها أحد.

وبالمواومة بين مسصطلح الأصـالة

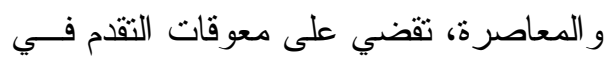

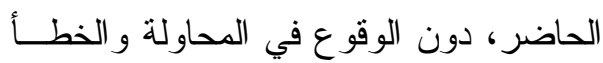
لمعرفة الماضي برؤية واعية (ro).

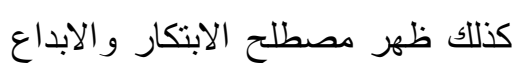
و الاختراع، بمعنى ابتكره واستتبطه ليعاصر

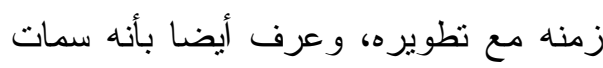

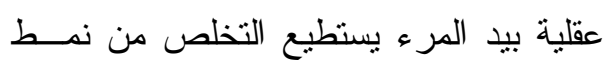

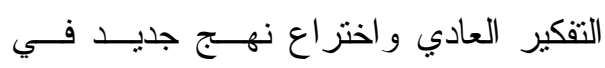

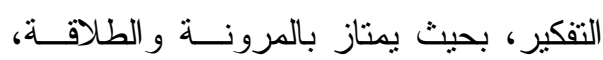

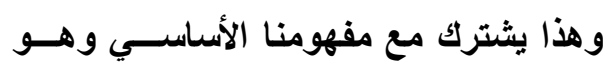

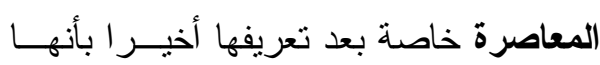

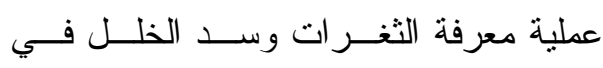

يعني جددها وحدثها، ومعاصنَر اسم مفهـول

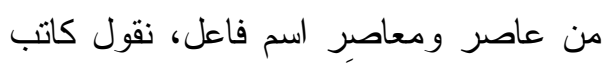

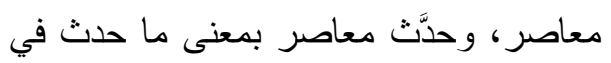
عصرك وزمانك (r (T).

المعاصرة اصطلاحا: تعني معايـشة

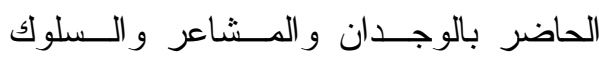

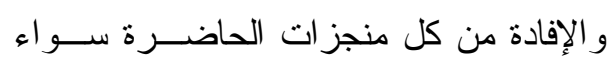

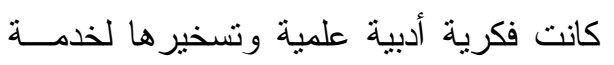

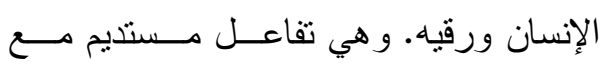

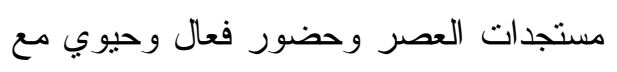
الحاضر والماضي مع منع تــأثير الجوانسب وحئب السلبية، والــصر اعات الدذهيبـــة والأفكــار

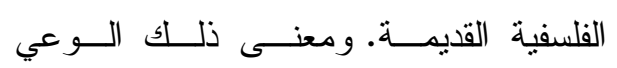

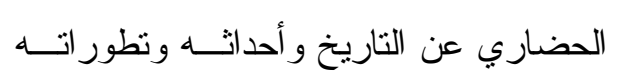
للعبور بالحاضر إلى المستقبل، وكذلك

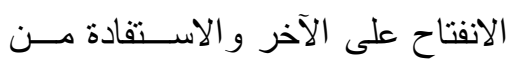

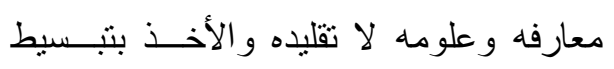

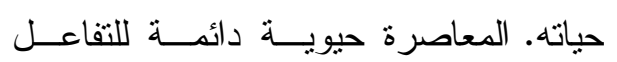
المستمر مع الو اقع بالأصالة (Tr)

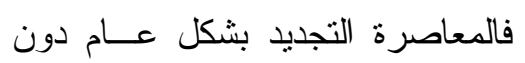

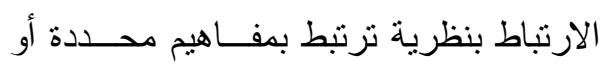

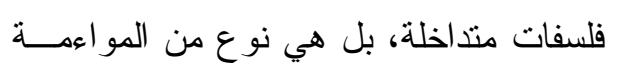

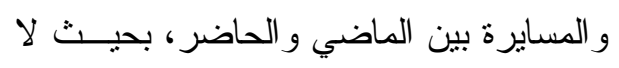

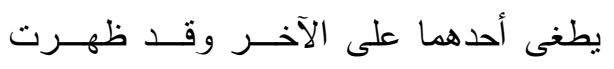
مصطلحات مستخدمة من مصطلح المعاصرة و هو مصطلح الأصالة. 


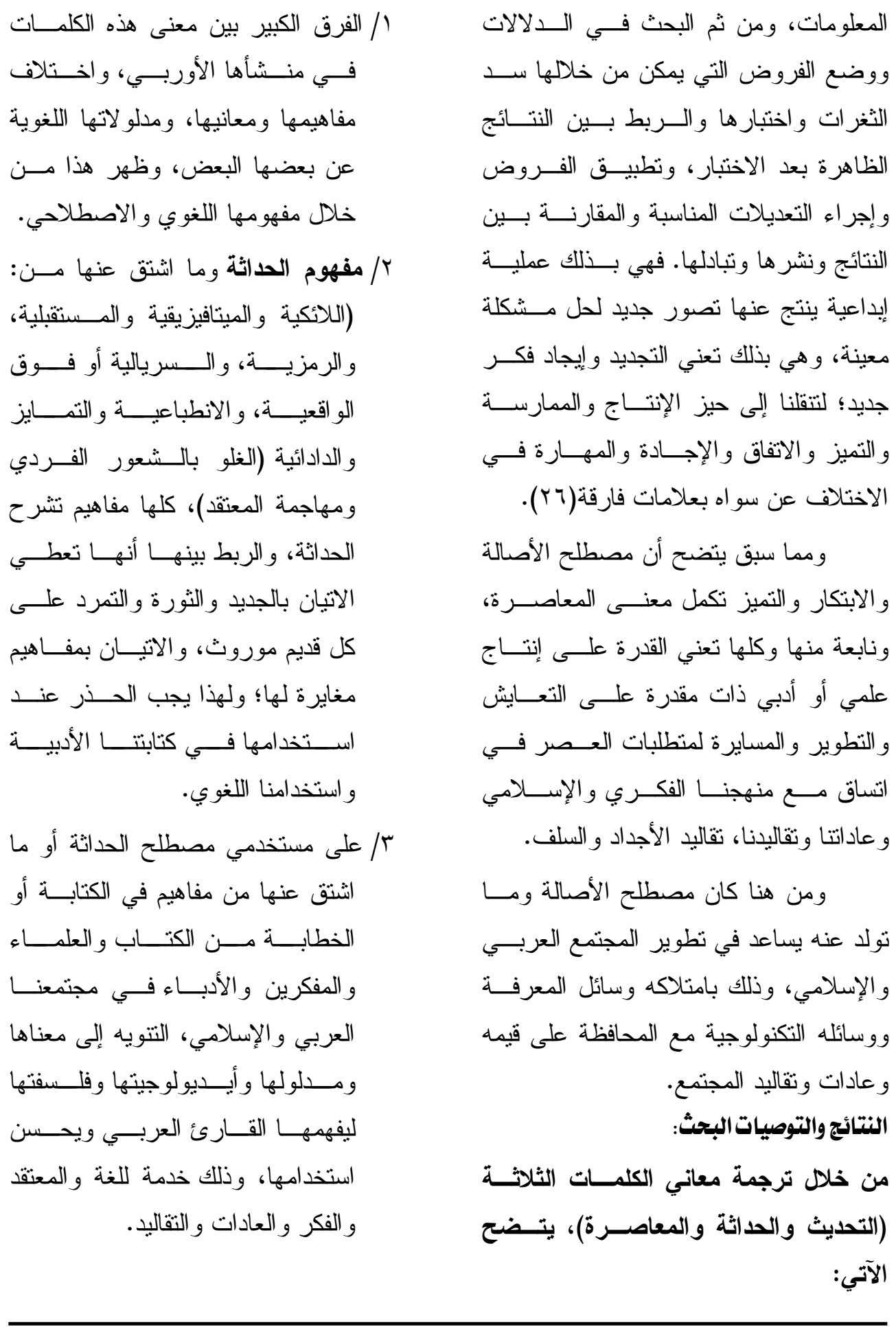


للتعبير عن نهضتتا الأدبية والثقافيــة و العلمية الحديثة كبديل عن مــصطلح

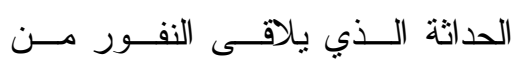
الناس.

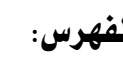

/ / المعجم الوسيط: مجمع اللغة العربيـة،

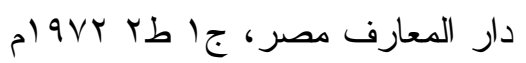
17.

/ / عدنان علي رضا النحــــي: نظريــة

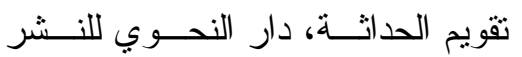

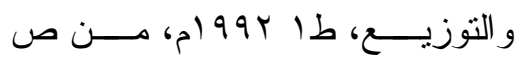
هrا إلى •ــ إنصرف.

/ / محمد محفوظ: فــي معنــى الحداثـــة

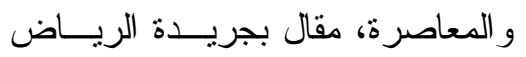

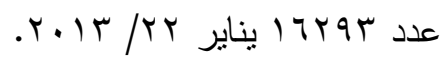
\& / أحمد علي (أورونيس): النص القرآني

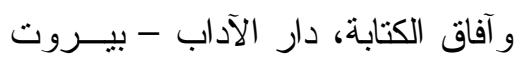

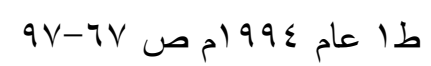
/ احمد محمد زايد مقــالات عـن نتــار

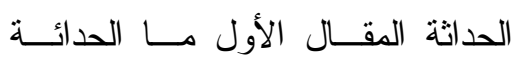
موقع saaid net / / خالد نصر الدين: مقال بعنوان من أجل

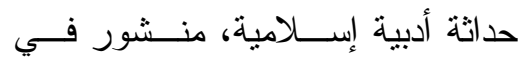

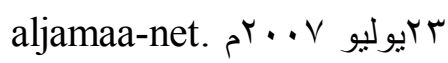

₹/ أما مصطلح التحديث وما نولد عنه من معان

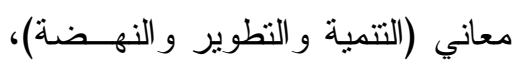

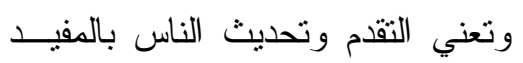

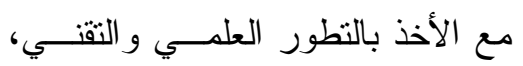

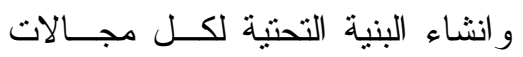
الحياة سو اء كانت روحية أو ماديــة،

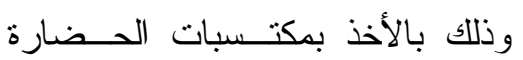

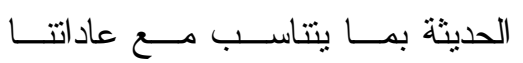
وتقاليدنا العربية و الإسلامية.

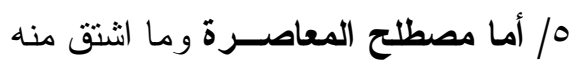

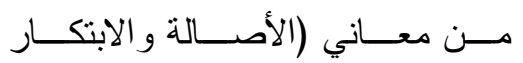
و الإبداع و التميز)، كلها مــصطلحات توضح معنى المعاصرة وفي الدلالــــة

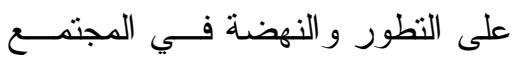
مما يسهل استخدامها في كتابتتا الأدبية و العلمية، و التعبير بها بمعان ثابتة في

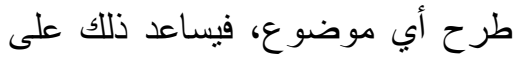

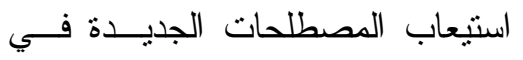

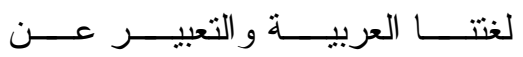

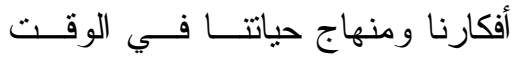
الحاضر • 7/ وجود الحاجة الملحة لاستخدام مصطلح

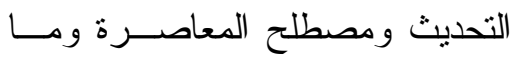

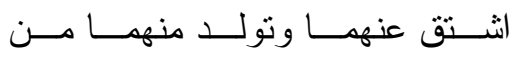
مصطلحات؛ للتعبير بهما في كتابتتــا الأدبية و اللغوية و العلمية وفى تعبير اتتا الحياتية المقرو عة و المسمو عة و المرئية 


$$
\begin{aligned}
& \text { كاظمة للنشر و التوزيـع و الترجمــة، } \\
& \text { / عدنان علي رضا النحوي: النظرية في }
\end{aligned}
$$

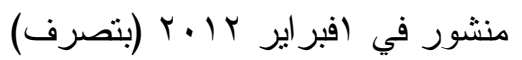

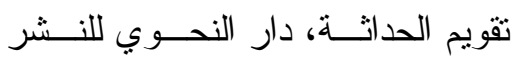

$$
\begin{aligned}
& \text { 17/ معجــم المعــاني الجــامع: كلمــة " } \\
& \text { www.almaany.com النتمية" } \\
& \text { / V إير اهيم العيسوي: التتمية فـي عـالم } \\
& \text { متغير دراسة فــي مفهــوم التتميــة }
\end{aligned}
$$

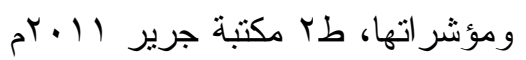

$$
\begin{aligned}
& \text { عدة صفحات ( بتصرف). } \\
& \text { 1/ / معجم المعاني الجامع، بــاب معنــى }
\end{aligned}
$$

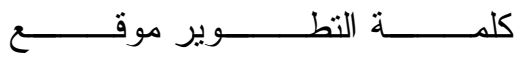

$$
\begin{aligned}
& \text { www.almaany.com } \\
& \text { 19/ مصطفى حلمي: الحداثــة وطريسـق } \\
& \text { النهضة، مقال منشور في Vاســبتمبر }
\end{aligned}
$$

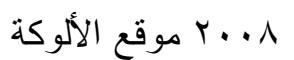

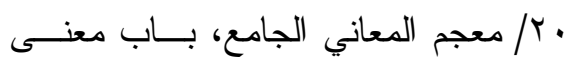

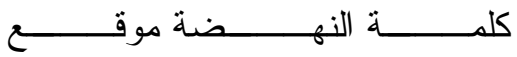

$$
\begin{aligned}
& \text { www.almaany.com } \\
& \text { آ/د.د. زكريا طاهر محمد العليو: النهضة } \\
& \text { في الوطن العربي البدايات ولأفــاق، }
\end{aligned}
$$

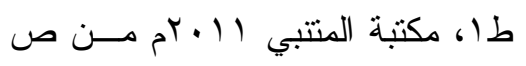

$$
\begin{aligned}
& \text { \9 } \\
& \text { r r / معجم المعاني الجامع باب المعاصرة } \\
& \text { almaany.com }
\end{aligned}
$$

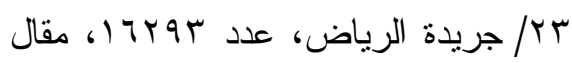

$$
\begin{aligned}
& \text { بعنوان" في معنى المعاصرة" للكاتــب } \\
& \text { محمد محفوظ، الثلاثاء • اربيع الأول }
\end{aligned}
$$

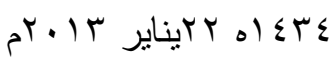

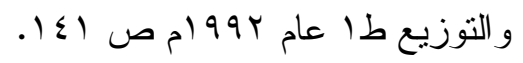

$$
\begin{aligned}
& \text { 9/ علي محمد الغريب: مقــال بعنــــان" }
\end{aligned}
$$

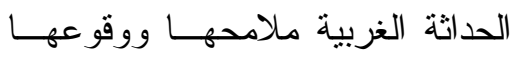

$$
\begin{aligned}
& \text { على الثقافة العربية" منــشور فــي مانه } \\
& \text { أكت } \\
& \text { www.lahaonline.com } \\
& \text { • / خالد نصر الدين: مقـــال مــن أجــل } \\
& \text { حداثة أدبية عربية إسلامية، منـشور }
\end{aligned}
$$

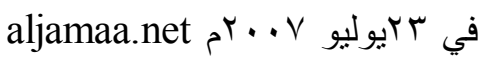

$$
\begin{aligned}
& \text { / / / على وطفة: مقاربات فــي مفهـومي } \\
& \text { الحداثة وما بعد الحداثة ص r مجلـــة } \\
& \text { فكر ونقد عدد عـ } \\
& \text { r / / عماد إيراهيم عبد الرازق: الحداثـــة }
\end{aligned}
$$

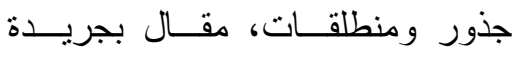

$$
\begin{aligned}
& \text { إيلاف، عدد V أغسطس } \\
& \text { ب ا// محمــــود أمهـــز : التيــــار ات الفتيـــة } \\
& \text { المعاصرة، شركة المطبوعات للتوزيع } \\
& \text { و النــشر بيــروت لبــنلن، طا عــام }
\end{aligned}
$$

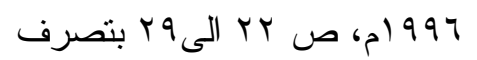

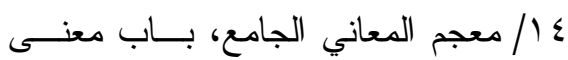

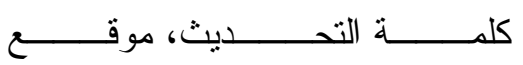

$$
\begin{aligned}
& \text { www.almaany.com } \\
& \text { 10/ جهينة سلطان يف العيسى: التحـديث } \\
& \text { في المجتمع القطري المعاصــر ، دار لئه }
\end{aligned}
$$




$$
\begin{aligned}
& \text { جب/ د. فرحات الـسليم، كتــاب الثقافــة } \\
& \text { ع / / معجم المعاني الجامع، بــاب معنـى } \\
& \text { العربية بين الأصــالة و المعاصــرة، }
\end{aligned}
$$

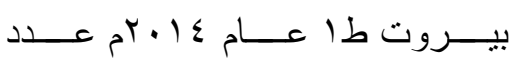

$$
\begin{aligned}
& \text { صفحات (بتصرف). }
\end{aligned}
$$

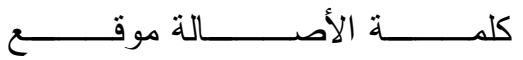

$$
\begin{aligned}
& \text { www.almaany.com }
\end{aligned}
$$

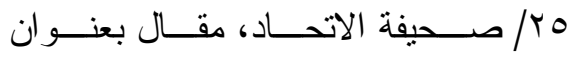

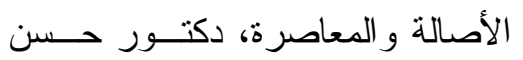

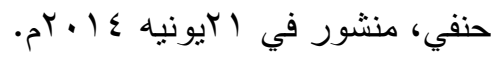

